\title{
MENYELARASKAN PERENCANAAN STRATEGI TEKNOLOGI INFORMASI YANG DIDASARKAN PADA STRATEGI MANAJEMEN TEKNOLOGI INFORMASI DAN STRATEGI BISNIS
}

\author{
Sandfreni ${ }^{1}$, Fransiskus Adikara ${ }^{2}$ \\ ${ }^{1,2}$ Program Studi Sistem Informasi, Fakultas Ilmu Komputer, Universitas Esa Unggul, \\ J1. Arjuna Utara, Jakarta, 11510, Indonesia

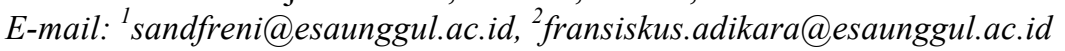

\begin{abstract}
Abstrak
Sukses dalam persaingan dalam sebuah bisnis terkait dengan pengembangan kompetensi inti, keselarasan strategi dan perencanaan strategis jangka panjang agar dapat mempertahankan keunggulan kompetitif dari sebuah bisnis. Sebuah perusahaan membutuhkan keselarasan antara strategi Teknologi Informasi dan Strategi Bisnis. Perencanaan Strategi Teknologi Informasi merupakan langkah pertama antara proses dari sebuah sistem informasi perusahaan dan merupakan pedoman dari system informasi perusahaan serta dasar pelaksanaan. Tulisan ini bertujuan untuk membahas bagaimana membuat perencanaan strategis Teknologi Informasi yang tepat. Setelah membahas Model Keselarasan Strategis dan hubungan antara Teknologi Informasi strategi dan strategi bisnis dapat nerencanakan rencana strategis yang didasarkan pada strategi bisnis, yang terdiri Teknologi Informasi penilaian dan analisis, perencanaan dan desain Teknologi Informasi serta implementasi dan desain Teknologi Informasi. Kemudian, memberikan contoh untuk menggambarkan bagaimana membuat perencanaan strategis Teknologi Informasi dengan menggunakan model tersebut.
\end{abstract}

Kata kunci-Strategi IT, Strategi Bisnis, Perencanaan Strategi IT, Model Strategi IT

\begin{abstract}
Success in competition in a business is related to the development of core competencies, strategic alignment and long-term strategic planning in order to maintain the competitive advantage of a business. A company needs alignment between IT strategy and Business Strategy. Planning IT Strategy is the first step between the processes of a company information system and is a guideline of the company's information system and the basis of implementation. This paper aims to discuss how to make appropriate IT strategic planning. After discussing the Strategic Alignment Model and the relationship between IT strategy and business strategy, it proposes strategic IT planning models based on business strategies, which consist of IT assessment and analysis, IT planning and design as well as IT implementation and design. Then, give an example to illustrate how to make IT strategic planning using the model.
\end{abstract}

Keywords-IT Strategic, Business Strategic, IT Strategic Plan, Model IT Strategic

\section{PENDAHULUAN}

Perkembangan enterprise saat ini menuntut agar enterprise membuat rencana strategi Teknologi Informasi yang akan digunakan untuk menjalankan bisnisnya. Peran Teknologi Informasi (TI) telah mengalami perubahan yang sangat signifikan, karena Teknologi Informasi saat ini diharapkan dapat menjadi bagian dari strategi suatu enterprise dalam mencapai tujuannya. Strategi Teknologi Informasi dalam sebuah enterprise menjadi perhatian utama dihampir seluruh bentuk enterprise. Hal ini dipicu dengan perkembangan ekonomi baru atau sering disebut ekonomi internet. Oleh karena itu perencanaan strategi Teknologi Informasi perlu 
dilakukan dengan tepat. Strategi Teknologi Informasi pada dasarnya terbagi dua bagian yaitu strategi sistem informasi dan strategi Teknologi Informasi. Strategi sistem informasi dapat berupa alur informasi yang digunakan maupun aplikasi pendukung. Sedangkan strategi teknologi Teknologi Informasi adalah strategi teknologi yang akan digunakan dalam menjalankan sistem informasi.

Dalam lingkungan konvensional, hubungan antara strategi kompetitif perusahaan dan manfaat penggunaan Teknologi Informasi dikembangkan melalui beberapa lapisan yaitu dari perencanaan, Analisa, dan perancangan. Dapat dipahami bila pada lingkungan seperti ini Teknologi Informasi memiliki pengaruh yang kecil terhadap strategi kompetitif perusahaan. Sejalan dengan semakin luasnya pemanfaatan Teknologi Informasi di lingkungan bisnis, semakin terlihat tidak ada lagi pemisahan antara Teknologi Informasi dan Strategi kompetitif perusahaan, karena semua strategi kompetitif harus memiliki Teknologi Informasi sama halnya dengan memiliki marketing, produsen dan keuangan. Strategi Teknologi Informasi membantu manager untuk mendefinisikan batasan pembuatan keputusan untuk tindakan berikutnya, tapi menghentikan dengan singkat dalam menentukan tindakan untuk dirinya sendiri. Hal ini merupakan perbedaan mendasar antara Strategi Teknologi Informasi dan perencanaan Teknologi Informasi.

Strategi Teknologi Informasi merupakan kumpulan prioritas yang menguasai pembuatan keputusan bagi user dan proses data profesional. Hal itu merupakan bentuk aturan framework untuk kegunaan Teknologi Informasi dalam perusahaan, dan menjelaskan bagaimana seorang eksekutif senior pada perusahaan akan berhubungan pada infrastruktur Teknologi Informasi. Perencanaan Teknologi Informasi memfokuskan pada pelaksanaan dari Strategi Teknologi Informasi. Oleh karena itu tujuan dari penelitian ini menyelaraskan rencana strategi Teknologi Informasi yang didasarkan pada strategi manajemen Teknologi Informasi dan strategi bisnis agar dapat meningkatkan daya saing perusahaan dan pada akhirnya membantu perusahaan mencapai strategi bisnis mereka.

Perkembangan dari era ekonomi pengetahuan membuat Teknologi Informasi menjadi kompetitif dan merupakan sebuah cara yang efektif untuk dapat membantu perusahaan bertahan di kalangan masyarakat modern dan mendapatkan efek pembangunan yang lebih besar. Dalam menghadapi ekonomi globalisasi ini, setiap perusahaan mulai merasa khawatir tentang sistem informasi untuk memperkuat daya saing mereka. Namun di beberapa negara, tingkat keberhasilan sebuah sistem informasi perusahaan tidak tinggi. Dari beberapa kasus perusahaan yang konstruksi sistem informasinya gagal, dapat dilihat bahwa sebagian besar perusahaan tidak membuat perencanaan Strategi Teknologi Informasi yang sistematis dan ilmiah pada tahap awal, sehingga perencanaan Strategi Teknologi Informasi menjadi tidak jelas dan penilaian menjadi tidak pasti dalam kriteria seleksi teknis. Sebaliknya, perusahaan-perusahaan yang sukses memiliki keseluruhan baik perencanaan Strategi Teknologi Informasi maupun Strategi Bisnis. Pembangunan tahap demi tahap sebuah sistem informasi dan memperbaiki sistem tersebut secara bertahap perlu dilakukan. Perencanaan Strategi Teknologi Informasi dan Strategi Bisnis untuk tahap demi tahap pelaksanaan adalah pilihan terbaik untuk pembagunan sistem informasi perusahaan. Secara keseluruhan perencanaan Strategi Teknologi Informasi dan Strategi Bisnis harus didasarkan pada pengembangan Strategi Bisnis di tingkat strategi dan kemudian mengembangkan perencanaan tindakan yang layak. 


\section{METODE PENELITIAN}

Pada penelitian dilakukan tahap-tahapan sebagai berikut:

1. Persiapan

2. Studi pustaka

3. Menyelaraskan Perencanaan Strategi Teknologi Informasi dan Strategi Bisnis

a. Fase penyelarasan perencanaan strategi Teknologi Informasi dengan strategi bisnis yang telah dijalankan perusahaan.

i. Formulasi Strategi Teknologi Informasi

ii. Perencanaan Teknologi Informasi

iii. Peningkatan Kualitas dan Program Inovasi Teknologi Informasi

b. Fase Pengembangan Organisasi

i. Strategi Teknologi Informasi

ii. Perencanaan Teknologi Informasi dan TQM/IS

Strategi Teknologi Informasi membantu manager untuk mendefinisikan batasan pembuatan keputusan untuk tindakan berikutnya, tapi menghentikan dengan singkat dalam menentukan tindakan untuk dirinya sendiri. Hal ini merupakan perbedaan mendasar antara Strategi Teknologi Informasi dan perencanaan Teknologi Informasi. Strategi Teknologi Informasi merupakan kumpulan prioritas yang menguasai pembuatan keputusan bagi user dan proses data profesional. Hal itu merupakan bentuk aturan framework untuk kegunaan IT dalam perusahaan, dan menjelaskan bagaimana seorang eksekutif senior pada perusahaan akan berhubungan pada infrastruktur Teknologi Informasi. Perencanaan Teknologi Informasi pada hal lain, memfokuskan pada pelaksanaan dari Strategi Teknologi Informasi.

Hal-hal yang termasuk dalam Teknologi Informasi adalah:

- Aplikasi proses transaksi

- Proses informasi dan aplikasi pelaporan

- Sistem pendukung keputusan

- Sistem pendukung eksekutif

- Produktivitas profesional dan alat berkelompok

- Sistem berbasis ilmu pengetahuan dan kecerdasan tiruan

- Proses automatisasi dan robotic

- Desain dan automatisasi pabrik; dan

- Teknologi yang berada dalam komputer (seperti "smartcard" atau ATMs)

Pendekatan Teknologi Informasi/Penyelarasan Strategi tidak hanya dirancang untuk menutup kemungkinan strategi Teknologi Informasi; berarti untuk memfasilitasi perundingan tentang kepercayaan manajemen dan pelatihan industri dengan:

- Mengajukan pertanyaan yang relevan dan membantu struktur individu yang mereka fikirkan dan percaya.

- Menjawab pertanyaan yang diajukan, berdasarkan pada pengalaman perusahaan.

- Membangun konsensus disekitar prinsip yang terbaik dalam memetakan kebutuhan dari lingkungan kompetitif; dan

- Membangun sebuah laporan review program untuk memastikan implementasi memantau pengembangan strategi, dan untuk mengubah prinsip sebagai pergantian kondisi.

Hal penting dalam proses Teknologi Informasi /Penyelarasan Strategi:

- Posisi dan lingkup aktifitas Teknologi Informasi;

- Kebutuhan resources dan batasan; dan

- Organisasi dan Manajemen Teknologi Informasi 


\section{HASIL DAN PEMBAHASAN}

\subsection{Rencana Strategi Teknologi Informasi dan Keuntungannya}

Perencanaan strategis Teknologi Informasi bergantung pada hasil penilaian Teknologi Informasi, itu akan mengembangkan atau menyesuaikan arahan sistem informasi dari perusahaan dan mengupayakan untuk skala yang paling cocok dan biaya yang paling pantas untuk mendapatkan informasi pekerjaan yang harus dilakukan. Pertama, sesuai dengan kebutuhan strategis perusahaan, kita harus memiliki visi dan misi yang jelas perusahaan dari teknologi informasi dan menentukan arah pembangunan sistem informasi perusahaan dan fungsi bisnis teknologi informasi dalam mencapai strategi bisnis proses. Kedua, kita perlu menyusun sebuah program untuk mengarahkan sistem kerja perusahaan. Karena ini merupakan konstitusi yang harus diikuti oleh departemen teknologi informasi ketika mengimplementasikan tugasnya. Pada saat yang sama, itu merupakan jaminan untuk menyelesaikan misi informasi secara efektif. Ketiga, tujuan Sistem informasi perusahaan harus didefinisikan karena mereka adalah tugas yang perlu dilakukan selama tahun-tahun mendatang untuk menjamin tercapainya visi dan misi.

Adapun keuntungan dari rencana strategi Teknologi Informasi:

- Perencanaan strategis Teknologi Informasi dapat mempromosikan konsistensi antara strategi bisnis dan item konstruksi sistem informasi perusahaan seperti kecepatan, arah, serta kemampuan memperbaiki perusahaan untuk mengendalikan Teknologi Informasi dan peningkatan daya saing perusahaan.

- Perusahaan dapat memutuskan apa yang harus difokuskan dan kinerja masa depan pengembangan usaha. Hal ini juga dapat menghindari fenomena bahwa produsen Teknologi Informasi tidak bertanggung jawab mengganggu perusahaan untuk meluncurkan informasi skala besar denganteknologi dalam mengejar keuntungan mereka sendiri.

- Perencanaan strategis Teknologi Informasi mempromosikan pemimpin eksekutif untuk mencapai konsensus pada ideologi, kunci mengarahkan bidang aplikasi dan faktor penentu keberhasilan sistem informasi.

- Perencanaan strategis Teknologi Informasi dapat membantu staf Teknologi Informasi dan staf aplikasi untuk mengetahui apa yang harus mereka miliki di masa depan, seperti pengetahuan, keterampilan, dan kriteria memilih teknologi.

- Perencanaan strategis Teknologi Informasi dapat membantu perusahaan untuk meningkatkan kemampuan meningkatkan pendapatan investasi Teknologi Informasi dan mengurangi risiko secara efektif.

\subsection{Rencana Strategi Teknologi Informasi Berdasarkan Bisnis Strategi}

Teknologi informasi mengubah cara perusahaan mengatur proses bisnis mereka, berkomunikasi dengan calon pelanggan dan memberikan layanan mereka. Faktor kunci keberhasilan untuk perusahaan yang sukses adalah keselarasan yang efektif dan efisien dalam mendukung strategi dan proses bisnis Teknologi Informasi (Lihat Gambar 1). Kebutuhan dan keinginan menyelaraskan kebutuhan bisnis dan kemampuan Teknologi Informasi. Dalam survei tahunan Manajemen Informasi, keselarasan Teknologi Informasi dan bisnis merupakan peringkat pertama yang mendapat perhatian dari enam tahun terakhir ini. Keselarasan antara bisnis kebutuhan dan kemampuan Teknologi Informasi masih merupakan area yang menonjol dari keprihatinan. Jadi, dapat dengan mudah dilihat bahwa membuat strategi Teknologi Informasi adalah bukan berarti murni masalah teknis, tetapi manajemen yang berorientasi dengan masalah. Strategi Teknologi Informasi harus fokus pada informasi dari pada teknologi karena sistem informasi itu sendiri tidak menciptakan informasi, informasi yang hanya dapat datang dari kegiatan tidak peduli melalui saluran apa. Tetapi kita perlu tahu sumber dan arah arus informasi ini adalah perencanaan strategis dasar Teknologi Informasi. Untuk itu kita harus 
mempunyai pemahaman mendalam tentang strategi bisnis dan struktur organisasi dari suatu perusahaan.

\subsubsection{Penyelarasan Strategi Teknologi Informasi}

Sebagaimana yang dinyatakan oleh Venkatraman, Henderson dan Oldach, Strategic Alignment Model (SAM) menjelaskan bisnis dan keselarasan Teknologi Informasi sepanjang dua dimensi (Gambar 1). Dimensi strategic fit membedakan antara fokus eksternal, diarahkan terhadap lingkungan bisnis, dan fokus internal serta struktur administrasi. Selanjutnya yaitu dimensi integrasi fungsional memisahkan bisnis dan Teknologi Informasi. Secara keseluruhan, model mendefinisikan empat domain yang telah diselaraskan untuk mencapai keselarasan. Masing-masing domain memiliki komponen penyusunnya: ruang lingkup, kompetensi, pemerintahan, infrastruktur, proses dan keterampilan. Henderson dan Venkatraman membayar perhatian luas dengan pendekatan yang berbeda untuk mencapai keselarasan ini. Mengikuti pendekatan yang lebih holistik ini, kita mendefinisikan penyelarasan bisnis dan Teknologi Informasi sebagai sejauh mana aplikasi Teknologi Informasi, infrastruktur dan organisasi, mengaktifkan dan mendukung strategi bisnis dan proses, serta proses untuk menyadari hal ini.

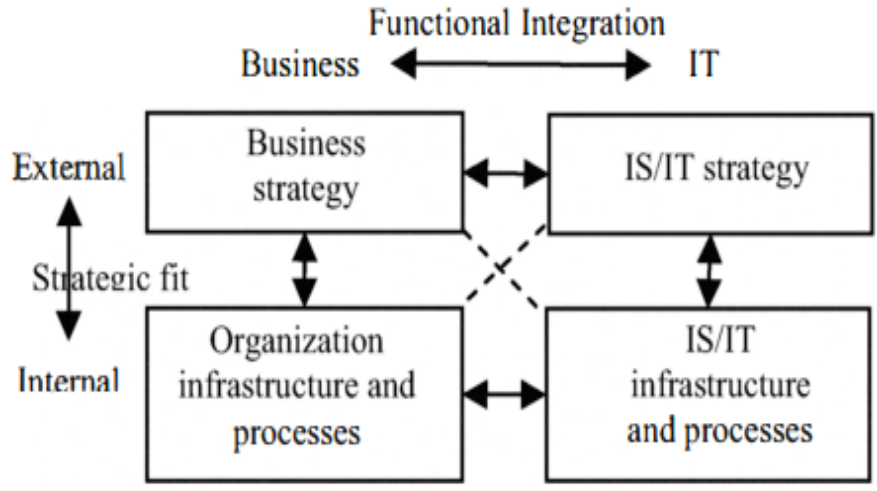

Gambar 1 Strategic Alignment Model (SAM)

\subsubsection{Model Rencana Strategi Teknologi Informasi Berdasarkan Strategi Bisnis}

Strategi Teknologi Informasi terkait erat dengan strategi bisnis. Teknologi Informasi akan menjadi pendorong untuk pengembangan usaha. Jika tidak, Teknologi Informasi akan menjadi tulang untuk suatu perusahaan. Dalam rangka untuk membuat kompetensi strategi Teknologi Informasi dengan strategi bisnis, orang perlu memahami hubungan antara Teknologi Informasi dan strategi dan tahu apa strategi bisnis dan akhirnya bekerja di luar strategi Teknologi Informasi yang sesuai dengan strategi bisnis. Gambar 2 adalah proses perencanaan strategi Teknologi Informasi berdasarkan strategi bisnis:

- Menilai dan menganalisis Teknologi Informasi untuk memahami apakah perusahaan memberikan layanan yang berkualitas kepada para penggunanya, perusahaan harus melakukan penilaian kemampuannya. Penilaian ini harus mencakup lima bidang utama: mendapatkan bisnis strategis perencanaan, fungsi bisnis perusahaan itu dan proses dasar; menganalisis bisnis, membedakan teknologi Teknologi Informasi dan gambaran besar tujuan pembangunan Teknologi Informasi; menganalisis kondisi sistem informasi saat ini; memeriksa apakah bisnis tersebut cocok dengan Teknologi Informasi; menilai infrastruktur Teknologi Informasi saat ini. 


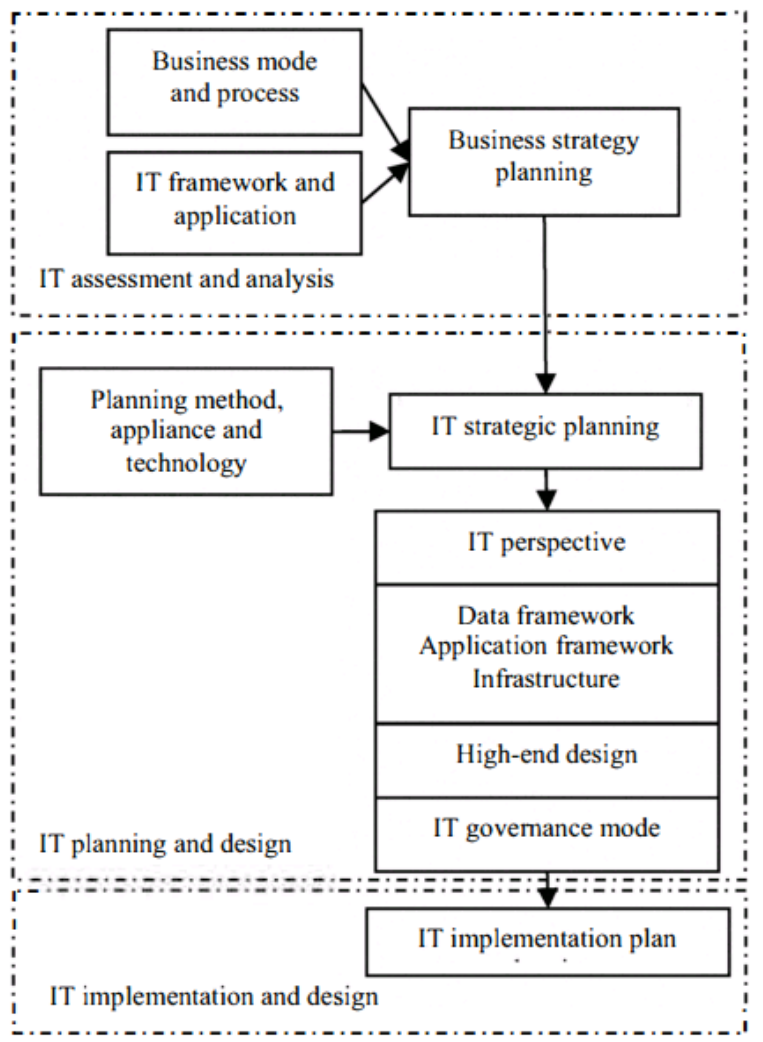

Gambar 2 Proses perencanaan strategi Teknologi Informasi berdasarkan strategi bisnis

- Perencanaan dan desain Teknologi Informasi. Strategi Teknologi Informasi, pembangunan kerangka Teknologi Informasi masa depan dan modus pengelolaan Teknologi Informasi di masa depan selesai dalam langkah ini. Strategi Teknologi Informasi meliputi: Teknologi Informasi perspektif yang menentukan efek dari Teknologi Informasi di perusahaan; kerangka perusahaan yang merupakan standar untuk merancang kerangka aplikasi, data kerangka kerja dan infrastruktur; desain high-end yang berisi standarisasi, operasi inti sistem, e-bisnis, platform database, strategi pusat data dan strategi pusat pemulihan bencana. Prinsip-prinsip utama adalah fasilitasi, standardisasi, modularisasi dan integrasi.

- Implementasi dan desain Teknologi Informasi. Tugas pada langkah ini menemukan faktor penentu keberhasilan, mendefinisikan dan menyortir proyek-proyek tertentu, mengkonfirmasikan waktu dan tugas untuk setiap langkah, memperkirakan anggaran dan peramalan hasil.

Mengembangkan perencanaan strategis dengan cara ini dapat membantu memastikan keselarasan kebutuhan bisnis dan aktivitas Teknologi Informasi. Memiliki rencana tersebut dapat menguntungkan perusahaan dalam beberapa cara. Pertama, rencana tersebut menyediakan arahan yang jelas untuk barang-barang penting. Proyek Teknologi Informasi harus jatuh ke dalam item penting dalam rencana, sehingga menghilangkan proyek yang tidak perlu. Kedua, semua orang akan harus "mendayung" ke arah yang sama. Ketika orang-orang baris di arah yang berlawanan, sedikit atau tidak ada kemajuan dalam bergerak perahu ke depan. Ketiga, tim keuangan bisnis akan memiliki tampilan tingkat tinggi mendanai kebutuhan Teknologi Informasi. Akhirnya, strategis perencanaan adalah cara yang baik untuk memotivasi departemen pengguna untuk membeli ke dalam strategi karena mereka erat terlibat dalam proses pengembangan strategi. 


\subsection{Pembahasan}

\subsubsection{Fase Penyelarasan Strategi Teknologi Informasi}

Proses aktual dari proses Teknologi Informasi /Penyelarasan strategi terdiri atas tiga fase, yaitu:

- Fase I - Formulasi strategi Teknologi Informasi

- Fase II - Perencanaan Teknologi Informasi

- Fase III - Peningkatan kualitas dan program inovasi Teknologi Informasi.

Fase I - Memperkirakan penyelarasan yang ada antara Teknologi Informasi dan strategi kompetitif dan memformulasikan strategi Teknologi Informasi yang baru. Beberapa jalan yang membuat strategi Teknologi Informasi dan strategi bisnis akan tidak sejajar, tapi sebagai titik awal:

- Hasil akhir dan kekayaan dalam satu level, tujuan dari strategi dan perencanaan adalah untuk menentukan bahwa bisnis yang memiliki kekayaan (resources, organisasi, dan proses) untuk meraih hasil akhir (goal, objektifitas, dan misi).

- Waktu tekanan lainnya dari penjajaran adalah perluasan yang akan datang dan melangkah kembali pada perubahan yang konsisten atara operasi bisnis dan IS.

- Objektifitas dan nilai sebuah bentuk umum dari ketidak sejajaran yang terjadi ketika objektifitas dan nilai dari bisnis tidak konsisten dengan objektifitas dan nilai manajemen IS.

Proses Teknologi Informasi /penyelarasan strategi dimulai dengan kebutuhan penafsiran strategi Teknologi Informasi dan diagnosa masalah yang mengizinkan eksekutif untuk menyediakan pengertian pada kebutuhan kritis, objektifitas, dan prioritas yang mereka hadapi. Jika memungkinkan, interview dapat dipimpin oleh anggota dari tiap grup berikut: senior management, senior functional professionals, staf analis, dan IS management.

Daftar pertanyaan untuk interview dan kuisioner dapat dirancang pada konsultasi dengan satu atau dua senior eksekutif untuk memastikan bahwa semua area yang penting dari aktifitas tercakupi. Cakupannya harus memiliki hal-hal berikut:

- Penjelasan singkat dari objektifitas, ruang lingkup, dan rencana dari proyek dan sebuah deskripsi dari metodologi;

- Objektifitas/prioritas/keputusan dari bisnis utama;

- Ruang untuk mengembangkan dukungan Teknologi Informasi (aplikasi dan/atau layanan);

- Interface dengan grup dan organisasi lain (internal dan eksternal);

- Proyeksi dari kebutuhan masa depan;

- Masalah kebijakan seperti kekuasaan, daya hitung dan persetujuan langsung; dan

- Feedback pada interview.

Setelah mengidentifikasi strategi bisnis organisasi, selanjutnya dapat diadakan workshop untuk eksekutif guna menjelaskan implikasi strategi kompetitif perusahaan terhadap eksplorasi Teknologi Informasi. Workshop ini dapat difasilitasi dengan agen netral atau mungkin konsultan, dan diawali dengan pemaparan strategi bisnis yang berhubungan dengan interview dan kuisioner, dokumen strategi yang ada, dan beberapa interview eksternal.

Strategi Teknologi Informasi yang didapat dari fase I terdiri dari beberapa elemen:

$>$ Penempatan dan target kesempatan;

- Asumsi kritis

- Aturan kompetitif Teknologi Informasi

- Sasaran dan ukuran dari nilai Teknologi Informasi

- Aplikasi strategi dan perkiraan resiko 
Kompetensi dasar;

- Kompetensi pengembangan sistem baru

- Kompetensi sistem operasi

- Sumber kompetensi.

Manajemen dan Organisasi

- Perencanaan dan tanggung jawab control

- Tanggung jawab ekseskusi dan operasi

- Hubungan bisnis/IS

- Resiko kooperatif

Fase II - Membangun pusat laba perencanaan Teknologi Informasi

Sebuah teknologi dan platform data adalah:

- Responsif dan adaptif dengan kebutuhan bisnis;

- Cocok (bila dibutuhkan) melalui unit bisnis; dan

- Dapat menembus dan menyebar dalam bisnis

Aplikasi inti yang modern, stabil, reliabel, dan mudah dipelihara dan bernilai tinggi. Sebuah lingkungan dengan:

- Pengembangan aplikasi yang besar/kemampuan yang besar;

- Alat pengembangan yang kuat; dan

- Staff yang terlatih dan kompeten.

$>$ Level tinggi dari tingkat kepuasan dengan Teknologi Informasi.

Perencanaan Teknologi Informasi adalah sebuah definisi dari masa depan yang memperbolehkan teknologi menjadi alat yang kompetitif, memberikan permasalahan dan kesempatan menghadapi bisnis.

Pengembangan sebuah perencanaan Teknologi Informasi dimulai dengan perkiraan pada lingkungan Teknologi Informasi yang ada untuk mendukung kegiatan bisnis. Hal ini termasuk perkiraan tentang aplikasi yang digunakan untuk bisnis, database dan struktur yang mendukung bisnis, dan teknologi yang digunakan. Perencanaan Teknologi Informasi menjelaskan mekanisne dimana Sistem Informasi dan bisnis dapat meningkatkan hubungan yang terpercaya, dengan pertimbangan sebagai berikut:

- Struktur dan penempatan

- Aturan dan tanggung jawab

- Performa dan sistem pelaporan; dan

- Pengguna dan pendidikan Isistem Informasi dan training.

Strategi Teknologi Informasi harus dihasilkan dari proses yang menyediakan platfomr dimana dibangunnya kegunaan teknologi informasi yang kompetitif, dan secara alami dapat diperluas program kualitas Teknologi Informasi yang akan mengganti keadaan yang ada.

Fase III - Membangun Program Kualitas Teknologi Informasi

Hal-hal yang perlu diperhatikan antara lain:

- Membangun strategi Teknologi Informasi yang dapat di kustomisasi dan perencanaannya untuk individu yang akan menghdapi tekanan kompetisi yang unik.

- Mengidentifikasi tanggung jawab IS yang cocok yang menyeimbangkan distribusi dari front line untuk menghadapi kemampuan untuk mengatur resource dengan personil front line.

- Meningkatkan struktur orientasi proses yang 


\subsubsection{Fase Pengembangan Organisasi}

Ketika pengembangan organisasi bukan suatu fase dalam metodologi Teknologi Informasi/penyelarasan strategi, hal ini merupakan suatu keahlian yang dibutuhkan diantara proses pada area yang beragam, tergantung pada proyek dan situasi yang terjadi pada client.

Fase I - Strategi Teknologi Informasi

$>$ Proses struktur interview profesional yang menghasilkan pengetahuan mendasar pada manajemen perspektif, end user, dan customer internal/supplier. Kumpulan struktur data dari semua peserta untuk memperoleh hasil akhir, persepsi, sikap, faktor motivasi dan kebiasaan pengumpulan data.

$>$ Keuntungan ketika merancang proses bisnis, dugaan idealistis tentang "kemungkinan yang ada" akan menjadi sesuatu yang serius. Resiko tergabung dengan implemetasi persoalan yang di perkecil ketika sebuah konsensus diraih dalam objektivitas.

$>$ Dapat disampaikan pengembangan konsensus dan komitmen dapat dikembangkan melalui tim, workshop focus-building. Sebuah perencanaan yang sehat dikontruksikan dengan pengembangan komponen organisasi yang terintegrasi.

Fase II - Perencanaan Teknologi Informasi dan fase III - TQM/IS

$>$ Proses Kebutuhan bisnis dijelaskan dengan konteks kenyataan organisasional. Kebutuhan ini di terjemahkan ke dalam spesifikasi kongkret dari teknologi dan perubahan organisasi. Dukungan struktur organisasional dan sistem penghargaan dianalisa dan diadaptasi untuk mempertemukan kebutuhan masa depan suatu organisasi.

$>$ Keuntungan rencana untuk perubahan dalam kebijakan organisasional dan praktisi dikembangkan untuk membuat dukungan maksimum untuk dan merangkul penerimaan dari end user.

$>$ Dapat disampaikan feedback yang sistematis dari review sebuah rencana dan memberikan laporan prosesnya dari strategi formulai, rencana dan program pengambangan Sistem Informasi

\section{KESIMPULAN}

Dalam pembahasan di atas, bahwa strategi Teknologi Informasi harus sesuai dengan strategi bisnis dan dapat menggambarkan bagaimana merumuskan strategi Teknologi Informasi yang sesuai dengan bisnis strategi, sebagai bagian integral dari strategi bisnis, dapat memenuhi kebutuhan bisnis yang lebih baik, meningkatkan daya saing inti perusahaan dan mencapai tujuan strategis perusahaan. Dari apa yang telah dibahas di atas, jelas bahwa perencanaan strategis Teknologi Informasi berdasarkan strategi bisnis menentukan arsitektur Teknologi Informasi masa depan, masukan dan perbaikan berdasarkan strategi bisnis, struktur organisasi, operasi proses dan status aplikasi Teknologi Informasi hanya teknologi informasi ini cocok untuk layanan manajemen dan teknologi informasi melayani manajemen strategi perusahaan dan manajemen bisnis, maka informasi teknologi dapat meningkatkan kapasitas berkelanjutan pengembangan usaha dan meningkatkan inti daya saing perusahaan dan semua ini pada akhirnya membantu perusahaan mencapai strategi bisnis mereka. 


\section{DAFTAR PUSTAKA}

[1] Alonso, I.A.; Verdun, J.C.; Caro, E.T., "The Importance of IT Strategic Demand Management in Achieving the Objectives of the Strategic Business Planning," Computer Science and Software Engineering, 2008 International Conference on , vol.2, no., pp.235,238, 12-14 Dec. 2008 doi: 10.1109/CSSE.2008.1307 URL:http://ieeexplore.ieee.org/stamp/stamp.jsp?tp=\&arnumber=4722042\&isnumber $=472$ 1981

[2] Nogueira, A.R.R.; Reinhard, N., "Strategic IT management in Brazilian banks," System Sciences, 2000. Proceedings of the 33rd Annual Hawaii International Conference on , vol., no., pp.9 pp. vol.2, 4-7 Jan. 2000 doi: 10.1109/HICSS.2000.926916 URL: $\mathrm{http} / / /$ ieeexplore.ieee.org/stamp/stamp.jsp?tp=\&arnumber=926916\&isnumber=20043

[3] Petruzzi, G.L.; Garavelli, A.C., "The strategic value of the "fit" between business processes and IT management: The case of the Italian publishing industry," BusinessDriven IT Management, 2007. BDIM '07. 2nd IEEE/IFIP International Workshop on , vol., no., pp.110,111, 21-21 May 2007 doi: 10.1109/BDIM.2007.375021 URL: $\mathrm{http} / /$ ieeexplore.ieee.org/stamp/stamp.jsp?tp=\&arnumber=4261110\&isnumber=4261089

[4] Abdi, M.; Dominic, P. D D, "Strategic IT alignment with business strategy: Service oriented architecture approach," Information Technology (ITSim), 2010 International Symposium in , vol.3, no., pp.1473,1478, 15-17 June 2010 doi: 10.1109/ITSIM.2010.5561624 URL: $\mathrm{http} / /$ ieeexplore.ieee.org/stamp/stamp.jsp?tp=\&arnumber=5561624\&isnumber $=5561452$ 